УДК 371.2: 378

DOI:

Наталія Свтушенко, кандидат педагогічних наук, доиент кафедри природничо-математичних дисииплін та інформаційно-комунікаційних технологій в освіті Чернігівського обласного інституту післядипломної педагогічної освіти імені К.Д. Уиинського

\title{
ПДВИЩЕННЯ КВАЛІФІКАЦІЇ ВЧИТЕЛІВ ПРИРОДНИЧО-МАТЕМАТИЧНИХ ПРЕДМЕТІВ У ПІСЛЯДИПЛОМНІЙ ОСВІТІ УКРАЇНИ ЯК ПРОБЛЕМА ПЕДАГОГІЧНОЇ ТЕОРЇ̈
}

У статті викладено результати аналізу стану проблеми підвищення кваліфікації вчителів природничоматематичних предметів у післядипломній освіті в педагогічній теорії. Визначено напрями наукового пошуку з обраної проблеми, а саме: теоретичні основи функціонування системи підвищення кваліфікації вчителів, розробка системи професійного розвитку вчителів, реалізація компетентнісного підходу до підвищення кваліфікації вчителів, теоретичні засади методичної підготовки вчителів в умовах неперервної освіти, підготовка вчителів до професійної діяльності.

Ключові слова: підвищення кваліфікаиї̈; учителі природничо-математичних предметів; післядипломна освіта; Україна.

Jim. 23.

Nataliya Yevtushenko, Ph.D.(Pedagogy), Associate Professor of the Natural and Mathematical Disciplines, Information and Communication Technologies in Education Department Chernihiv Kostyantyn Ushynskiy Regional Institute of Postgraduate Pedagogical Education

\section{QUALIFICATION IMPROVEMENT OF TEACHERS OF NATURALAND MATHEMATICAL SUBJECTS IN POSTGRADUATE EDUCATION OF UKRAINE AS A PROBLEM OF PEDAGOGICAL THEORY}

The article presents the results of the analysis of the state of the problem of professional development of teachers of natural sciences and mathematics in postgraduate education in pedagogical theory. The author identifies the areas of research on the selected problem, namely: theoretical foundations of functioning of the in-service teacher training system, development and justification of the system of professional development of teachers, implementation of a competency-based approach into the process of in-service teacher training, theoretical principles of teacher training in continuing education, and training teachers for various types of professional activities.

It is noted that the study of scientific publications, in particular, allowed to characterize the system of professional development of teachers of science and mathematics in postgraduate education and determine the levels of its organizational structure (national, regional), local (city, district, united territorial community), the level of the educational institution where the teacher works directly.

In accordance with the generalization of the results of dissertation research, a conclusion was made on the content of advanced training of teachers of natural sciences and mathematics in postgraduate education, which today is determined primarily by the need for teachers to acquire new competencies within their professional activities.

It is noted that the analysis of scientific works in the field of teacher training for various types of professional activities contributed to the development and implementation of content and methodological support for training in the program of advanced training of teachers of natural and mathematical subjects in postgraduate education.

It is concluded that the issue of conducting a thorough study of the pedagogical phenomenon "professional development of teachers of natural sciences and mathematics in postgraduate education", summarizing some theoretical provisions and generalizing them to a single system is relevant. Ukraine.

Keywords: certification training; teachers of natural and mathematical subjects; postgraduate education;

П остановка проблеми. Актуальність дослідження проблеми підвищення кваліфікації вчителів природничоматематичних предметів у післядипломній освіті зумовлена необхідністю підвищення якості природничо-математичної освіти, ії значенням для формування математичної та природничонаукової компетентності молодого покоління, оскільки незаперечним $€$ факт суттєвого впливу природничих наук і математики на економіку 


\section{ПІДВИЩЕННЯ КВАЛІФІКАЦІЇ ВЧИТЕЛІВ ПРИРОДНИЧО-МАТЕМАТИЧНИХПРЕДМЕТІВ У ПІСЛЯДИПЛОМНІЙ ОСВІТІ УКРӒ̈НИ ЯК ПРОБЛЕМА ПЕДАГОГІЧНОЇ ТЕОРІЇ}

держави, що відбувається внаслідок швидкого розвитку окремих галузей та нових технологій, які визначають рівень життя нації.

Аналіз останніх досліджень і публікацій. У працях А. Зубка, В. Киркалова, М. Кагана, С. Крисюка, А. Кузьминського, В. Маслова, Н. Ничкало, В. Олійника, Н. Протасової, В. Пуцова, Г. Сльникової, В. Сидоренко, Т. Сорочан, В. Якуніна розроблені концептуальні положення щодо організації й розвитку системи післядипломної педагогічної освіти, аналізуються теоретичні основи розвитку системи підвищення кваліфікації вчителів у післядипломній освіті, акцентується увага на необхідності її оновлення.

Виділення не вирішених раніше частин загальної проблеми. Водночас незважаючи на достатній рівень наукового осмислення проблематики післядипломної педагогічної освіти, окремі її напрями, зокрема підвищення кваліфікації вчителів природничо-математичних предметів у післядипломній освіті, висвітлені недостатньо та потребують подальшої деталізації як у теоретичному, так і практичному аспектах.

Формулювання цілей статті. Мета статті - здійснити аналіз стану висвітлення проблеми підвищення кваліфікації вчителів природничоматематичних предметів у післядипломній освіті у педагогічній теорії.

Викладення основного матеріалу. Науковий аналіз обраної проблеми показав, що підвищення кваліфікації вчителів, зокрема природничоматематичних предметів, у педагогічній теорії досліджувалося українськими вченими у таких аспектах, як: теоретичні основи функціонування системи підвищення кваліфікації вчителів; розробка й обгрунтування системи професійного розвитку вчителів; реалізація компетентнісного підходу до підвищення кваліфікації вчителів; теоретичні засади методичної підготовки вчителів в умовах неперервної освіти; окремі питання удосконалення професійної підготовки вчителів у сучасних умовах.

Теоретичні основи функціонування системи підвищення кваліфікації вчителів у своїх працях досліджували В. Арешонков [1], С. Бачинська [3], А. Зубко [13], Н. Протасова [18]. Науковцями розглянуто питання, які розкривають педагогічні засади самоорганізації слухачів системи післядипломної педагогічної освіти, організаційнометодичні засади підготовки вчителів до класного керівництва в системі підвищення кваліфікації, організаційно-педагогічні умови удосконалення освітнього процесу в системі підвищення кваліфікації, теоретико-методичні основи функціонування системи післядипломної освіти педагогів в Україні.
Як справедливо зазначає Н. Протасова [18], розвиток системи післядипломної освіти вчителів характеризується об'єктивно наявними, суттєвими зв'язками явищ освіти та суспільного життя, серед яких iī “'залежність від об'єктивних і суб' єктивних чинників суспільного життя, єдність і взаємозв'язок розвитку та збагачення в процесі післядипломної освіти загальнокультурної, фаховокваліфікаційної та функціональної складових сукупної культури вчителя, взаємозв'язок післядипломної освіти вчителя з його активною самоосвітою, саморозвитком і самовихованням, залежність ефективності післядипломної освіти від доцільно організованої діяльності та розумно побудованого спілкування в ії процесі” $[18,13]$.

Вивчення наукових публікацій, дало змогу схарактеризувати систему підвищення кваліфікації вчителів природничо-математичних предметів у післядипломній освіті й визначити рівні іiі організаційної структури (загальнонаціональний, регіональний (рівень області), локальний (рівень містя, району, об'єднаної територіальної громади) та рівень освітнього закладу, в якому безпосередньо працює вчитель.

Питання організації освітнього процесу в системі підвищення кваліфікації вчителів у післядипломній освіті вивчалися у працях Н. Білик [4], К. Гораш [9], Л. Зазуліної [12]. Науковцями розглянуто проблеми моделювання процесу навчання у системі підвищення кваліфікації вчителів, інформаційне забезпечення впровадження освітніх інновацій у систему підвищення кваліфікації вчителів, діалогізація дидактичного процесу в курсовій підготовці вчителів.

Вивчення цих досліджень дало підставу для висновку, процес у закладах післядипломної педагогічної освіти грунтується на принципах андрагогіки й акмеології, практичної спрямованості, інформатизації, гнучкості й мобільності, випередження, інтеграції, диференціації та індивідуалізації змісту підвищення кваліфікації, неперервності навчання, принципах відкритої освіти.

Зокрема, організація освітнього процесу в інститутах післядипломної педагогічної освіти/ академіях неперервної освіти здійснюється за освітньо-професійними/професійними програмами підвищення кваліфікації очної (денної), дистанційної, очно-дистанційної форм здобуття освіти, а також за індивідуальними програмами (графіками), за програмами особистісного i професійного розвитку, які реалізуються у формі тренінгів, семінарів, консультацій, майстер-класів, за програмами формальної та неформальної 


\section{ПІДВИЩЕННЯ КВАЛІФІКАЦІЇ ВЧИТЕЛІВ ПРИРОДНИЧО-МАТЕМАТИЧНИХПРЕДМЕТІВ У ПІСЛЯДИПЛОМНІЙ ОСВІТІ УКРАЇНИ ЯК ПРОБЛЕМА ПЕДАГОГІЧНОӤ ТЕОРІЇ}

післядипломної освіти. Відповідно до запитів і потреб споживачів освітніх послуг, закладами пропонуються тематичні, авторські, модульні курси підвищення кваліфікації тощо [5].

Важливе значення для нашого дослідження має розгляд системи професійного розвитку вчителів природничо-математичних дисциплін у післядипломній освіті, що розкривається у праці М. Бирка [5] як “єдиний комплекс структурних і функціональних компонентів (форм, методів, засобів, умов і змісту), а системоутворювальним фактором цієї системи є професійний розвиток учителів природничо-математичних дисциплін” $[5,136]$. Провідною ідеєю дослідження вченого $€$ “розуміння професійного розвитку вчителя природничо-математичних дисциплін як обов'язкової складової його професійної діяльності, що забезпечує фахове зростання вчителя відповідно до вимог соціуму та індивідуальних освітніх потреб” $[5,5]$. Дослідником розроблено й методологічно обгрунтовано авторську систему професійного розвитку вчителів природничо-математичних дисциплін у післядипломній освіті.

На нашу думку, цінними є результати дослідження I. Жорової “Розвиток професіоналізму вчителів природничих дисциплін у системі післядипломної освіти України (1940-і рр. XX початок XXI ст.)" [11]. Праця присвячена вивченню історико-теоретичного аспекту питання професійного розвитку вчителів природничих дисциплін. Дослідження грунтується на розгляді детермінант, змісту, форм і методів розвитку професіоналізму вчителів природничих дисциплін у системі післядипломної освіти як “складного і суперечливого, неперервного і гетерохронного процесу, що відбувається під впливом суспільнополітичних, структурно-організаційних, змістовнотехнологічних, галузевих освітніх чинників" [11, 3]. Зокрема, дослідниця виокремлює в історії розвитку професіоналізму вчителів природничих дисциплін у системі післядипломної освіти України організаційно-пошуковий, адаптаційно-політехнічний, реформаторсько-новаторський, технологічнотворчий періоди $[11,9]$.

Реалізації компетентнісного підходу до підвищення кваліфікації вчителів природничоматематичних предметів у системі підвищення кваліфікації вчителів як складникової післядипломної освіти, присвячено студії П. Грабовського [8], Н. Лісової [15], О. Норкіної [16], В. Саюк [19], С. Смирнової-Трибульскої [21]. Зокрема, науковцями вивчалися питання розвитку таких видів компетентностей фахівців: інформаційної компетентності вчителів природничо- математичних предметів у післядипломній педагогічній освіті, загальнокультурної компетентності вчителів математики в системі післядипломної освіти, дослідницької компетентності вчителів математики засобами інформаційно-комунікативних технологій, професійної компетентності вчителів географії у системі післядипломної педагогічної освіти.

Потрібно зауважити, що впровадження компетентнісного підходу в освітній процес підвищення кваліфікації вчителів природничоматематичних предметів у післядипломній освіті стало новим концептуальним орієнтиром модернізації системи післядипломної педагогічної освіти - “багатоаспектного” утворення, яке передусім стосується мети, змісту та результатів освітнього процесу й передбачає формування в особи певної системи компетентностей [2]. Серед основних напрямів підвищення кваліфікації вчителів на сьогодні вважаються розвиток професійних компетентностей (знання навчального предмету, фахових методик, технологій) й формування у здобувачів освіти спільних для ключових компетентностей умінь (Закон України “Про освіту”) [17]. Зміст підвищення кваліфікації вчителів природничоматематичних предметів у післядипломній освіті визначається необхідністю набуття вчителями нових компетентностей у межах їх професійної діяльності, галузі знань, зокрема формуванні та розвитку цифрової, управлінської, комунікаційної, медійної, інклюзивної та мовленнєвої компетентностей [10]

У контексті нашого дослідження увагу привертають праці вітчизняних науковців С. Болсун [6], В. Вітюк [7], В. Луніної [14], в яких розкриті питання розвитку педагогічної техніки вчителя у процесі підвищення кваліфікації, професійно-особистісних якостей вчителівпредметників у системі післядипломної освіти, творчого потенціалу вчителя в умовах центру освітніх інновацій інституту післядипломної педагогічної освіти. Дослідниця В. Луніна зауважує: “'запит на творчість учителя, здатного працювати інноваційно є пріоритетним як для вітчизняної, так і для європейської педагогіки в цілому” $[14,5]$. Поняття “творчий потенціал учителя” розкривається науковцем як “складна динамічна характеристика особистості педагога, інтегрована сукупність пізнавального ресурсу, творчих можливостей і здібностей, готовності до інноваційної педагогічної діяльності, здатності до творчого саморозвитку та самовдосконалення" $[14,10]$.

У рамках нашого дослідження привертають 


\section{ПІДВИЩЕННЯ КВАЛФІКАЦЇ̈ ВЧИТЕЛІВ ПРИРОДНИЧО-МАТЕМАТИЧНИХПРЕДМЕТІВ УПІСЛЯДИПЛОМНІЙ ОСВІТІ УКРАЇНИ ЯКПРОБЛЕМА ПЕДАГОГІЧНОӤ ТЕОРІЇ}

увагу праці О. Бабкової [2], І. Сотніченко [20], Н. Ткачук [22], В. Шарко [23], що присвячені питанням підвищення професійної підготовки вчителів у сучасних умовах розвитку освіти й суспільства. Результати досліджень українських науковців сприяють розв'язанню таких питань, як: формування готовності вчителів природничих спеціальностей у післядипломній освіті до оцінювальної діяльності, підготовка вчителів до профільного навчання старшокласників у системі підвищення кваліфікації, підготовка вчителів природничих дисциплін до формування життєвих компетенцій учнів профільної школи в системі післядипломної освіти. Також В. Шарко [23] досить глибоко обгрунтовано теоретичні засади методичної підготовки вчителя фізики в умовах неперервної освіти.

Зауважимо, що соціальна структура особистості вчителя формується насамперед у професійній діяльності. Тому цілями підвищення кваліфікації вчителів у післядипломній освіті стає професійна підготовка в умовах реформування шкільної освіти. Здійснений аналіз наукових праць за цим напрямом у нашому дослідженні сприяв розробленню та впровадженню змістовнометодичного забезпечення для навчання за програмою підвищення кваліфікації вчителів природничо-математичних предметів у післядипломній освіті.

Висновки. Таким чином, проаналізувавши дослідження, присвячені підвищенню кваліфікації вчителів у післядипломній освіті України, ми дійшли висновку, що в них досить грунтовно розроблені теоретичні й практичні засади підвищення кваліфікації вчителів (цілі, зміст, організація, принципи, форми і методи). Також наявні спроби створення моделей розвитку професійної компетентності вчителів, вивчені окремі питання розвитку особистісних якостей учителів, розглянуто психолого-педагогічні засади їхнього професійного розвитку та підвищення кваліфікації.

Водночас потрібно зауважити, що у науковій літературі проблеми підвищення кваліфікації вчителів природничо-математичних предметів у післядипломній освіті України висвітлені досить фрагментарно. Таким чином, актуальним $\epsilon$ питання проведення більш грунтовного дослідження педагогічного явища “підвищення кваліфікації вчителів природничо-математичних предметів у післядипломній освіті”, зведення окремих теоретичних положень та їх узагальнення до єдиної системи.

Перспективами подальших розвідок в обраному напрямі $є$ систематизація окремих теоретичних положень щодо шляхів вдосконалення процесу підвищення кваліфікації вчителів природничо-математичних предметів у післядипломній освіті та узагальнення їх до єдиної системи.

\section{ЛІТЕРАТУРА}

1. Арешонков В. Ю. Педагогічні засади самоорганізації слухачів системи післядипломної педагогічної освіти: автореф. дис. ... канд. пед. наук. Житомир, 2006. 22 с.

2. Бабкова О. О. Формування готовності вчителів природничих спеціальностей у післядипломній освіті до оцінювальної діяльності: автореф. дис. ... канд. пед. наук. Запоріжжя, 2015. $24 \mathrm{c}$.

3. Бачинська Є. М. Організаційно-методичні засади підготовки вчителів до класного керівництва в системі підвищення кваліфікації: автореф. дис. .... канд. пед. наук. Київ, 2004. 22 с.

4. Білик Н. І. Моделювання процесу навчання в системі підвищення кваліфікації вчителів: автореф. дис. ... канд. пед. наук. Київ, 2005. 24 с.

5. Бирка М. Ф. Система професійного розвитку вчителів природничо-математичних дисциплін: дис. ... доктр. пед. наук. Запоріжжя, $2016.438 \mathrm{c}$

6. Болсун С. А. Розвиток педагогічної техніки вчителя в процесі підвищення кваліфікації: автореф. дис. ... канд. пед. Київ, 2002. 24 с.

7. Вітюк В. В. Розвиток професійноособистісних якостей вчителів-предметників в системі післядипломної освіти: автореф. дис. ... канд. пед. наук. Київ, 2000. 20 с.

8. Грабовський П. П. Розвиток інформаційної компетентності вчителів природничоматематичних предметів у післядипломній педагогічній освіті: автореф. дис. ... канд. пед. наук. Житомир, 2016. 24 с.

9. Гораш К. В. Інформаційне забезпечення впровадження освітніх інновацій у систему підвищення кваліфікації педагогічних працівників: автореф. дис. ... канд. пед. наук. Київ, 2000. 24 с.

10. Дробін А. А. Змістовне наповнення програм підвищення кваліфікації вчителів фізики в умовах реформування післядипломної педагогічної освіти. Наукові записки. 2020. 1(85). C. $98-102$.

11. Жорова I. Я. Розвиток професіоналізму вчителів природничих дисциплін у системі післядипломної освіти України (1940-і рр. XX початок XXI ст.): автореф. дис. ... док-ра пед. наук. Тернопіль, 2015.40 с.

12. Зазуліна Л. В. Інформаційне забезпечення впровадження освітніх інновацій у систему 


\section{ПШДВИЩЕННЯ КВАЛІФІКАЦЇ̈ ВЧИТЕЛІВ ПРИРОДНИЧО-МАТЕМАТИЧНИХПРЕДМЕТІВ У ПІСЛЯДИПЛОМНІЙ ОСВІТІ УКРАЇНИ ЯК ПРОБЛЕМА ПЕДАГОГІЧНОӤ ТЕОРІІ}

підвищення кваліфікації педагогічних працівників: автореф. дис. ... канд. пед. наук. Київ, 2000. 18 с.

13. Зубко А. М. Організаційно-педагогічні умови удосконалення навчального процесу в системі підвищення кваліфікації педагогічних кадрів: автореф. дис. ... канд. пед. наук. Київ, 2002. $20 \mathrm{c}$.

14. Луніна В. Ю. Розвиток творчого потенціалу вчителя в умовах центру освітніх інновацій інституту післядипломної педагогічної освіти: дис. ... кан-та пед. наук. Київ, 2016. 336 с.

15. Лісова Н. І. Розвиток психолого-педагогічної компетентності молодих учителів у системі післядипломної освіти: спец. дис. ... канд. пед. наук. Київ, 2005. 20 с.

16. Норкіна О. В. Розвиток дослідницької компетентності вчителів математики засобами інформаційно-комунікативних технологій: автореф. дис. ... канд. пед. наук. Умань, 2017. 24 с.

17. Про освіту: Закон України від 05.09.2017 p. № 2145-VIII. Голос України. 2017. № 178-179.

18. Протасова Н. Г. Теоретико-методичні основи функціонування системи післядипломної освіти педагогів в Україні: автореф. дис. на здобуття наук. ступеня док. пед. наук. Київ, 2005. $34 \mathrm{c}$.

19. Саюк В. І. Розвиток професійної компетентності вчителів географії у системі післядипломної педагогічної освіти: авторефер. дис. ... канд. пед. наук. Київ, 2007. 24 с.

20. Сотніченко I. I. Підготовка вчителів природничих дисциплін до профільного навчання старшокласників у системі підвищення кваліфікації: автореф. дис. ... канд. пед. наук. Київ, 2009. $20 \mathrm{c}$.

21. Смирнова-Трибульска Є. М. Теоретикометодичні основи формування інформатичних компетентностей вчителів природничих дисциплін у галузі дистанційного навчання: автореф. дис. ... доктр. пед. наук. Київ, 2008. 44 с.

22. Ткачук Н. М. Підготовка вчителів природничих дисциплін до формування життєвих компетенцій учнів профільної школи в системі післядипломної освіти: автореф. дис. ... канд. пед. наук. Київ, 2012. 24 с.

23. Шарко В. Д. Теоретичні засади методичної підготовки вчителя фізики в умовах неперервної освіти: автореф. дис. ... д-ра пед. наук. Київ, 2006. $44 \mathrm{c}$.

\section{REFERENCES}

1. Areshonkov, V. Yu. (2006). Pedahohichni zasady samoorhanizatsii slukhachiv systemy pisliadyplomnoi pedahohichnoi osvity [Pedagogical principles of self-organization of students in the system of postgraduate pedagogical education]. Extended abstract of candidate's thesis. Zhytomyr, $22 \mathrm{p}$. [in Ukrainian].

2. Babkova, O. O. (2015). Formuvannia hotovnosti vchyteliv pryrodnychykh spetsial'nostej u pisliadyplomnij osviti do otsiniuvalnoi diialnosti [Formation of readiness of teachers of natural specialties in postgraduate education to evaluation activities]. Extended abstract of candidate's thesis. Zaporizhzhia, 24 p. [in Ukrainian].

3. Bachynska, Ye. M. (2004). Orhanizatsijnometodychni zasady pidhotovky vchyteliv do klasnoho kerivnytstva $\mathrm{v}$ systemi pidvyschennia kvalifikatsii [Organizational and methodological principles of teacher training for classroom management in the system of advanced training]. Extended abstract of candidate's thesis. Kyiv, 22 p. [in Ukrainian].

4. Bilyk, N. I. (2005). Modeliuvannia protsesu navchannia $\mathrm{v}$ systemi pidvyschennia kvalifikatsii vchyteliv [Modeling of the learning process in the system of teacher training]. Extended abstract of candidate's thesis.Kyiv, 24 p. [in Ukrainian].

5. Byrka, M. F. (2016). Systema profesijnoho rozvytku vchyteliv pryrodnycho-matematychnykh dystsyplin [The system of professional development of teachers of natural and mathematical disciplines]. Doctor's thesis. Zaporizhzhia, 438 p. [in Ukrainian].

6. Bolsun, S. A. (2002). Rozvytok pedahohichnoi tekhniky vchytelia $\mathrm{v}$ protsesi pidvyschennia kvalifikatsii [Development of pedagogical technique of a teacher in the process of professional development]. Extended abstract of candidate's thesis. Kyiv, 24 p. [in Ukrainian].

7. Vitiuk V. V. (2000). Rozvytok profesijnoosobystisnykh iakostej vchyteliv-predmetnykiv v systemi pisliadyplomnoi osvity [Development of information competence of teachers of natural and mathematical subjects in postgraduate pedagogical education]. Extended abstract of candidate's thesis. Kyiv, 20 p. [in Ukrainian].

8. Hrabovskyj, P. P. (2016). Rozvytok informatsijnoi kompetentnosti vchyteliv pryrodnycho-matematychnykh predmetiv u pisliadyplomnij pedahohichnij osviti [Information support for the introduction of educational innovations in the system of professional development of teachers]. Extended abstract of candidate's thesis. Zhytomyr, 24 p. [in Ukrainian].

9. Horash, K. V.(2000). Informatsijne zabezpechennia vprovadzhennia osvitnikh innovatsij u systemu pidvyschennia kvalifikatsii pedahohichnykh pratsivnykiv [Information support for the introduction of educational innovations in the system of professional development of teachers]. Extended abstract of candidate's thesis. Kyiv, 24 p. [in Ukrainian]. 


\section{ПІДВИЩЕННЯ КВАЛІФІКАЦІЇ ВЧИТЕЛІВ ПРИРОДНИЧО-МАТЕМАТИЧНИХПРЕДМЕТІВ У ПІСЛЯДИПЛОМНІЙ ОСВІТІ УКРАЇНИ ЯКПРОБЛЕМА ПЕДАГОГІЧНОӤ ТЕОРІЇ}

10. Drobin, A. A. (2020). Zmistovne napovnennia prohram pidvyschennia kvalifikatsii vchyteliv fizyky $\mathrm{v}$ umovakh reformuvannia pisliadyplomnoi pedahohichnoi osvity [Content of in-service training programs for physics teachers in the context of reforming postgraduate pedagogical education]. Scientific notes. 1(85). pp. 98-102. [in Ukrainian].

11. Zhorova, I. Ya. (2015). Rozvytok profesionalizmu vchyteliv pryrodnychykh dystsyplin u systemi pisliadyplomnoi osvity Ukrainy (1940-i rr. XX pochatok XXI st.) [Development of professionalism of teachers of natural sciences in the system of postgraduate education of Ukraine (1940s of the XX - beginning of the XXI century)]. Extended abstract of candidate's thesis. Ternopil, $40 \mathrm{p}$. [in Ukrainian].

12. Zazulina, L. V. (2000). Informatsijne zabezpechennia vprovadzhennia osvitnikh innovatsij u systemu pidvyschennia kvalifikatsii pedahohichnykh pratsivnykiv [Information support for the introduction of educational innovations in the system of professional development of teachers]. Extended abstract of candidate's thesis. Kyiv, $18 \mathrm{p}$. [in Ukrainian].

13. Zubko, A. M. (2002). Orhanizatsijnopedahohichni umovy udoskonalennia navchalnoho protsesu v systemi pidvyschennia kvalifikatsii pedahohichnykh kadriv [Organizational and pedagogical conditions for improving the educational process in the system of professional development of teachers]. Extended abstract of candidate's thesis. Kyiv, 20 p. [in Ukrainian].

14. Lunina, V. Yu. (2016). Rozvytok tvorchoho potentsialu vchytelia v umovakh tsentru osvitnikh innovatsij instytutu pisliadyplomnoi pedahohichnoi osvity [Development of creative potential of a teacher in the conditions of the center of educational innovations of the institute of postgraduate pedagogical education]. Candidate's thesis. Kyiv, 336 p. [in Ukrainian].

15. Lisova, N. I. (2005). Rozvytok psykholohopedahohichnoi kompetentnosti molodykh uchyteliv u systemi pisliadyplomnoi osvity [Development of psychological and pedagogical competence of young teachers in the system of postgraduate education]. Candidate's thesis. Kyiv, 20 p. [in Ukrainian].

16. Norkina, O. V. (2017). Rozvytok doslidnytskoi kompetentnosti vchyteliv matematyky zasobamy informatsijno-komunikatyvnykh tekhnolohij [Development of research competence of mathematics teachers by means of information and communication technologies]. Extended abstract of candidate's thesis. Uman, 24 p. [in Ukrainian].

17. Pro osvitu: Zakon Ukrainy vid 05.09.2017 r. № 2145-VIII [On education]. Government courier. No. 186. [in Ukrainian].

18. Protasova, N. H. (2005). Teoretykometodychni osnovy funktsionuvannia systemy pisliadyplomnoi osvity pedahohiv v Ukraini [Theoretical and methodological bases of functioning of the system of postgraduate education of teachers in Ukraine]. Extended abstract of doctor's thesis. Kyiv, 34 p. [in Ukrainian].

19. Saiuk, V. I. (2007). Rozvytok profesijnoi kompetentnosti vchyteliv heohrafii u systemi pisliadyplomnoi pedahohichnoi osvity [Development of professional competence of geography teachers in the system of postgraduate pedagogical education]. Extended abstract of candidate's thesis. Kyiv, 24 p. [in Ukrainian].

20. Sotnichenko, I. I. (2009). Pidhotovka vchyteliv pryrodnychykh dystsyplin do profil'noho navchannia starshoklasnykiv u systemi pidvyschennia kvalifikatsii [Preparation of teachers of natural sciences for specialized training of high school students in the system of teacher training]. Extended abstract of candidate's thesis. Kyiv, $20 \mathrm{p}$. [in Ukrainian].

21. Smyrnova-Trybulska, Ye. M. (2008). Teoretykometodychni osnovy formuvannia informatychnykh kompetentnostej vchyteliv pryrodnychykh dystsyplin $\mathrm{u}$ haluzi dystantsijnoho navchannia [Theoretical and methodological bases of formation of information competencies of teachers of natural sciences in the field of distance learning]. Extended abstract of doctor's thesis. Kyiv, 44 p. [in Ukrainian].

22. Tkachuk, N. M. (2012). Pidhotovka vchyteliv pryrodnychykh dystsyplin do formuvannia zhyttievykh kompetentsij uchniv profilnoi shkoly v systemi pisliadyplomnoi osvity [Preparation of teachers of natural sciences for the formation of life competencies of the profile school students in the system of postgraduate education]. Extended abstract of candidate's thesis. Kyiv, 24 p. [in Ukrainian].

23. Sharko V. D. (2006). Teoretychni zasady metodychnoi pidhotovky vchytelia fizyky $\mathrm{v}$ umovakh neperervnoi osvity Theoretical bases of methodical preparation of the teacher of physics in the conditions of continuous education]. Extended abstract of doctor's thesis. Kyiv, 44 p. [in Ukrainian].

Стаття надійшла до редакції 18.06.2020

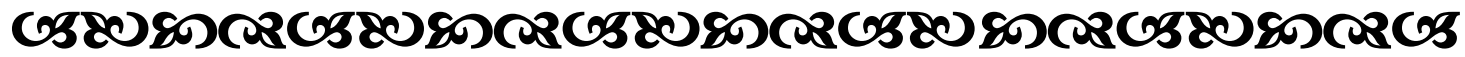

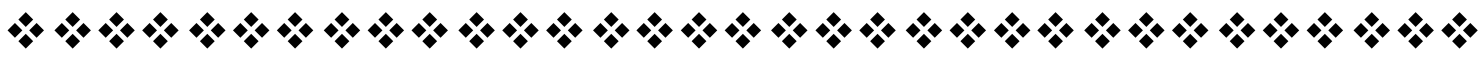

